Published in final edited form as:

Adv Healthc Mater. 2019 February ; 8(4): e1801363. doi:10.1002/adhm.201801363.

\title{
Organ-on-a-Chip for Cancer and Immune Organs Modeling
}

\section{Dr. Wujin Sun,}

Department of Bioengineering, University of California-Los Angeles, Los Angeles, CA 90095, USA, khademh@ucla.edu; Center for Minimally Invasive Therapeutics (C-MIT), California NanoSystems Institute, University of California-Los Angleles, Los Angeles, CA 90095, USA

\section{Dr. Zhimin Luo,}

Department of Bioengineering, University of California-Los Angeles, Los Angeles, CA 90095, USA, khademh@ucla.edu; Center for Minimally Invasive Therapeutics (C-MIT), California NanoSystems Institute, University of California-Los Angleles, Los Angeles, CA 90095, USA; School of Pharmacy, Xi'an Jiaotong University, Xi'an 710061, China

Dr. Junmin Lee,

Department of Bioengineering, University of California-Los Angeles, Los Angeles, CA 90095, USA, khademh@ucla.edu; Center for Minimally Invasive Therapeutics (C-MIT), California NanoSystems Institute, University of California-Los Angleles, Los Angeles, CA 90095, USA

\section{Dr. Han-Jun Kim,}

Department of Bioengineering, University of California-Los Angeles, Los Angeles, CA 90095, USA, khademh@ucla.edu; Center for Minimally Invasive Therapeutics (C-MIT), California NanoSystems Institute, University of California-Los Angleles, Los Angeles, CA 90095, USA

\section{Dr. KangJu Lee,}

Department of Bioengineering, University of California-Los Angeles, Los Angeles, CA 90095, USA, khademh@ucla.edu; Center for Minimally Invasive Therapeutics (C-MIT), California NanoSystems Institute, University of California-Los Angleles, Los Angeles, CA 90095, USA

\section{Peyton Tebon,}

Department of Bioengineering, University of California-Los Angeles, Los Angeles, CA 90095, USA, khademh@ucla.edu; Center for Minimally Invasive Therapeutics (C-MIT), California NanoSystems Institute, University of California-Los Angleles, Los Angeles, CA 90095, USA

\section{Yudi Feng,}

Department of Bioengineering, University of California-Los Angeles, Los Angeles, CA 90095, USA, khademh@ucla.edu; Center for Minimally Invasive Therapeutics (C-MIT), California NanoSystems Institute, University of California-Los Angleles, Los Angeles, CA 90095, USA; College of Chemistry, Nankai University, Tianjin 300071, China

\section{Dr. Prof. Mehmet R. Dokmeci,}

Department of Bioengineering, University of California-Los Angeles, Los Angeles, CA 90095, USA, khademh@ucla.edu; Center for Minimally Invasive Therapeutics (C-MIT), California NanoSystems Institute, University of California-Los Angleles, Los Angeles, CA 90095, USA; Department of Chemical and Biomolecular Engineering, University of California-Los Angeles, Los Angeles, CA 90095, USA

\section{Dr. Prof. Shiladitya Sengupta, and}


Brigham and Women's Hospital, Harvard Medical School, Boston, MA 02115, USA, shiladit@mit.edu; Harvard - MIT Division of Health Sciences and Technology, Cambridge, MA 02139, USA

\section{Dr. Prof. Ali Khademhosseini}

Department of Bioengineering, University of California-Los Angeles, Los Angeles, CA 90095, USA, khademh@ucla.edu; Center for Minimally Invasive Therapeutics (C-MIT), California NanoSystems Institute, University of California-Los Angleles, Los Angeles, CA 90095, USA; Jonsson Comprehensive Cancer Center, University of California - Los Angeles, 10833 Le Conte Ave, Los Angeles, CA 90024, USA.; Department of Chemical and Biomolecular Engineering, University of California-Los Angeles, Los Angeles, CA 90095, USA; Department of Radiology, University of California-Los Angeles, Los Angeles, CA 90095, USA; Center of Nanotechnology, Department of Physics, King Abdulaziz University, Jeddah 21569, Saudi Arabia; Department of Bioindustrial Technologies, College of Animal Bioscience and Technology, Konkuk University, Seoul, Republic of Korea

\section{Abstract}

Bridging the gap between findings in preclinical two dimensional (2D) cell culture models and in vivo tissue cultures has been challenging; the simple microenvironment of 2D monolayer culture systems may not capture the cellular response to drugs accurately. Three dimensional (3D) organotypic models have gained increasing interest due to their ability to recreate precise cellular organizations. These models facilitate investigation of the interactions between different sub-tissue level components through providing physiologically relevant microenvironments for cells in vitro. The incorporation of human-sourced tissues into these models further enable personalized prediction of drug response. Integration of microfluidic units into the 3D models can be used to control their local environment, dynamic simulation of cell behaviors, and real-time readout of drug testing data. Cancer and immune system related diseases are severe burdens to our health care system and have created an urgent need for high-throughput, effective drug development plans. In this review, we focus on recent progress in the development of "cancer-on-a-chip" and "immune organs-on-a-chip" systems designed to study disease progression and predict drug-induced response. Future challenges and opportunities are also discussed.

\section{Abstract}

Organ-on-a-chip systems can provide high-throughput platforms for drug development, which could potentially bridge the gap between $2 \mathrm{D}$ cell culture and animal models. With recent breakthroughs in anticancer immunotherapies, there is an increasing interest in organotypic models for anticancer immunotherapy development. Here, we review current progress in canceron-a-chip and immune organs-on-a-chip systems with an emphasis on their potential in drug development.

\section{Keywords}

organ-on-a-chip; organoids; cancer; immune system; drug screening 


\section{Introduction}

The cost of developing new drugs has been increasing steadily with analytical validations of drug efficacy and toxicity constituting major portions of spending. ${ }^{[1]}$ Poor correlation between outcomes in pre-clinical and clinical trials (due to unrepresentative pre-clinical models) has led to the majority of drug candidates failing to reach the market. Even after drugs are approved for clinical use, they have been recalled due to severe cardiac, liver or kidney toxicity. ${ }^{[2]}$ Moreover, the improper evaluation of the side effects of several prescription drugs has led to the hospitalization of many patients. ${ }^{[3]}$ Current pre-clinical research depending on 2D cell culture and animal models must be improved to reduce drug development costs and improve patient outcomes. ${ }^{[4]}$

Organoids are 3D cell cultures that self-assemble into miniature organs ex vivo. These models aim to bridge the gap between 2D cell culture and in vivo systems by providing an unlimited supply of organs to study normal and diseased physiology. ${ }^{[5]}$ This approach does not have the ethical issues or limitations associated with human organ donations. ${ }^{[6]}$ Three dimensional tissue culture is capable of generating samples suitable for cost-effective, highthroughput drug screening in which human drug response could be predicted in vitro in a timely manner. Using patient-derived tissue samples, these platforms show potential for personalized drug screening in which the in vitro test results can guide the prescription of drugs. In addition to modeling human organs, organoids also provide a means to obtain viable tissues in vitro for implantation ${ }^{[7]}$ - these implants could exhibit matched phenotypes of the target tissues and be implemented in regenerative therapies.

Organotypic structures can be generated by biofabrication techniques capable of organizing cells in a spatially-precise manner, such as biomaterial scaffold engineering ${ }^{[8]}$ and 3Dbioprinting. ${ }^{[9]}$ To replicate the physiology of the organs, the biofabrication approach must replicate the physical properties of the extracellular matrix (ECM) such as rigidity, porosity, density, and topography specific to the intended organ. ${ }^{[10]}$ Many factors can impact the phenotype of 3D organoids. Phenotypes can be influenced by: biomechanical forces and bioelectrical stimulations, which significantly impact stem cells; ${ }^{[11]}$ various local sitespecific cells, such as stromal cells or infiltrated immune cells, ${ }^{[12]}$ as well as signaling factors and nutrient gradients. ${ }^{[13]}$ With a better understanding of the physiology of organs, more parameters will be discovered to help guide the rational design of in vivo-like tissues. Many characterization techniques, such as immunohistochemical staining and transcriptome /proteome profiling, have been implemented to ensure that organoids generated in vitro can faithfully represent their counterparts in vivo. ${ }^{[14]}$ With advanced sectioning-based imaging techniques such as confocal and light-sheet microscopy, ${ }^{[15]}$ more information can be obtained at the cellular, tissue, and organ levels to validate similar behavior between in vitro models and in vivo systems.

By merging 3D organotypic system culture with microfluidics, the term "organ-on-a-chip" was coined. ${ }^{[16]}$ Poly (dimethylsiloxane) (PDMS)-based elastomeric devices facilitate convenient modeling of the in vivo body fluid perfusion-on-a-chip. Externally controlled microfluidics can simulate the blood flow in organs, recreating dynamic nutrient distribution in addition to mechanical cues, like shear stress, in the artificial tissues. By linking different 
organs-on-a-chip, microfluidic systems have the potential to simulate the complexity of multi-organ metabolism and pharmacokinetics of drugs. ${ }^{[17]}$ With further integration of noninvasive bio-sensors into microfluidic chips, ${ }^{[18]}$ facile monitoring of cell behavior, particularly drug response, is possible. The organ-on-a-chip approach has already been adopted into modeling many types of healthy and diseased tissues, such as cystic fibrosis, ${ }^{[19]}$ microvascular obstructions, ${ }^{[20]}$ neuropsychiatric disorders, ${ }^{[21]}$ kidney functions, ${ }^{[22]}$ and lung functions. ${ }^{[16]}$

In this review, we cover recent progress in engineering 3D models for cancer and immune tissues that replicated characteristics of their in vivo counterparts. We review "organs-on-achip" applications in investigating the fundamental biology of cancer and immune systems as well as the discovery of therapeutics (Figure 1). Challenges and potential opportunities regarding cancer and immune organs-on-a-chip are also discussed.

\section{Cancer modeling}

\subsection{Cancer organoids}

Tumors have a complex microenvironment, including a dense ECM, assorted stromal and immune cells, ${ }^{[23]}$ irregular vessels, and limited perfusion of nutrients - each of these can significantly affect the efficacy of administered therapies. ${ }^{[24]}$ Cancer organoids are better at maintaining tumor-like architecture and the composition of primary tumors than 2D cancer cell culture ${ }^{[25]}$ The indefinite proliferation of cancer organoids also enables the construction of organoid banks which allow systematic investigation of cancer variations; these banks have already been created for breast cancer, ${ }^{[26]}$ colorectal cancer, ${ }^{[27]}$ and bladder cancer. ${ }^{[28]}$ It has been demonstrated that both primary tumor ${ }^{[27]}$ and metastatic cancer-derived cells can generate organoids in vitro. ${ }^{[29]}$ Organotypic cancer models have been built for various types of cancers including pancreatic cancer, ${ }^{[30]}$ liver cancer, ${ }^{[31]}$ bladder cancer, ${ }^{[32]}$ colorectal cancer, ${ }^{[33]}$ breast cancer, ${ }^{[34]}$ brain cancer, ${ }^{[35]}$ cervical cancer, ${ }^{[36]}$ and prostate cancer. ${ }^{[37]}$

Cancer organoid models that faithfully reflect the phenotypes specific to an individual patient could be used to predict patient response to drug therapies. ${ }^{[38]}$ This approach would supplement existing genomic profiling-based precision medicine. Majumder et al. recreated the intratumoral heterogeneity of cancer and stromal cell distribution by culturing thin tumor sections. The sections maintain cellular distribution when cultured in tumor grade-matched matrix containing patient-derived serum. ${ }^{[39]}$ By investigating samples from 109 patients and analyzing the data for squamous cell carcinoma and colorectal cancer treatment using machine learning, anticancer drug sensitivity in another group of 55 patients was predicted. In another study, Valeri and his team built a gastrointestinal cancer organoid bank using 110 cancer biopsies collected from 71 patients using an image-guided biopsy procedure (Figure 2). ${ }^{[29]}$ These cancers were either metastatic or heavily pretreated and they were dissociated from the biopsy and suspended in Matrigel to generate the organoids. These patient-derived organoids showed high genotypic and phenotypic similarity to the original in vivo tumors. Upon treatment using a library of 55 drugs, organoid response mimicked patient response this correlation is evidence that patient-derived tumor organoids can be used to predict patient-specific drug responses. 
In addition to using patient-derived cell lines for tumor modeling, genetic engineering has been used to develop induced cancer models used to investigate tumorigenesis genes. ${ }^{40]}$ Manato et al. built colon organoids using normal colon epithelial cells. ${ }^{[11]}$ CRISPR-Cas9mediated gene editing was performed in the normal organoid to induce malignancy and generate a colonic adenocarcinoma model. Targeted gene disruptions were induced into five key genes associated with tumorigenesis (suppressor genes: APC, SMAD4, TP5; oncogenes: KRAS, PIK3CA) and the genetically modified cells were further selected using a predesigned culture medium. It was concluded that mutating the five key genes transformed normal colon epithelial cells into a cancerous phenotype that proliferates in vitro and forms a tumor after in vivo engraftment. However, this model was unable to replicate the invasive metastasis of colon cancer, indicating that other factors are involved in the metastatic process. The further development and implementation of genetic tools for organoid engineering, such as base editing, ${ }^{[42]}$ can make cancer organoids a more powerful model for investigating tumorigenesis.

\subsection{Cancer-on-a-chip}

By integrating cancer organotypic culture with microfluidic devices, "cancer-on-a-chip" systems allow recreation of the tumor microenvironment. These chips facilitate a better understanding of cancer behavior in vivo which leads to improved pre-clinical assessment of drug efficacy. By linking different physiological modules, including vasculature, ${ }^{[43]}$ canceron-a-chip models can further investigate the interactions between cancer and other organs. For example, Zervantonakis et al. simulated the 3D interface between cancer and blood vessels to investigate cancer cell invasion of the bloodstream (intravasation). ${ }^{[44]}$ Macrophages were incorporated into the model to study their role in inducing carcinoma intravasation. By tracking the interactions between different compartments using real-time imaging, it was found that macrophage-mediated vascular damage facilitated the intravasation of cancer cells. Cancer metastasis is a complex process dependent on the crosstalk between "seed" cancer cells and "soil" tissues; cytokines secreted by the target organ attract cancer cells to the metastatic site. To study this "seed-soil" process, Jeon et al. demonstrated a breast cancer extravasation chip that included muscle and bone mimicking units for studying organ selective cancer extravasation. ${ }^{[45]}$ A microvascular-like gel was lined with endothelial cells and embedded with bone mimicking stem cells to attract cancer cell extravasation. This model was used to emulate bone-specific extravasation of breast cancer cells to study the underlying pathways involved in cancer metastasis and screen antimetastasis drugs. Besides intravasation and extravasation, microfluidics has been used to model other tumorigenesis processes, including angiogenesis, ${ }^{[46]}$ invasiveness, ${ }^{[47]}$ migration, ${ }^{[48]}$ and adhesion. ${ }^{[49]}$

Microfluidic chips are advantageous not only due to their ability to link different modules to simulate multi-organ systems but also for their compatibility with online analytical modules for real-time monitoring of organoid status. For example, Zhang et al. demonstrated a "cancer-on-a-chip" platform that integrated multiple organoid models, including liver cancer and cardiac organoids (Figure 3). ${ }^{[50]}$ The multi-organ system was arranged to simulate metabolism of doxorubicin (DOX) in vivo. The authors integrated multiple sensors into a microfluidic breadboard including: an optical sensor for organoid morphology imaging; 
biochemical sensors for biomarker detection; and physical sensors for monitoring temperature, oxygen, and $\mathrm{pH}$. Multi-organ interactions and real-time sensing enabled dynamic monitoring of the efficacy and toxicity of DOX. This system allowed long-term, automated monitoring of organoid responses, which eliminated the need for laborious sampling and reduced potential disturbances to the system. Both the anti-cancer efficacy and the liver metabolism-mediated cardiac toxicity of DOX were accurately mimicked by the microfluidic system. Here, we briefly introduce the topic of "cancer-on-a-chip", which is not sufficient to cover the extensively investigated area. Readers are referred to a few comprehensive reviews for more details. ${ }^{[51]}$

\section{Immune organs modeling}

Immune therapy based on vaccination has made a great contribution to public health by providing durable protection against specific pathogens. ${ }^{[52]}$ Recent breakthroughs in engineering $\mathrm{T}$ cells, such as immune checkpoint inhibitors and chimeric antigen receptor $\mathrm{T}$ cell (CAR-T) therapies, ${ }^{[53]}$ have attracted significant attention to the development of immune therapies. These treatments are promising methods of not only activating the immune system against cancer and pathogens but also pacifying the immune system in case of autoimmune diseases ${ }^{[54]}$ in which the immune system attacks healthy host tissues.

Currently, investigations of immunotherapies are performed in either cellular or animal models; ${ }^{[55]}$ however, cell culture-based studies lack the complexity of in vivo microenvironment, and differences between the immune systems of animals and humans often lead to biased results. ${ }^{[56]}$ Drugs having favorable results in cell or animal studies could potentially suffer from serious setbacks in human trials. Negative results in the clinical trials of CAR-T therapies ${ }^{[57]}$ and the inefficacy of many types of drugs in humans ${ }^{[58]}$ are examples of the poor translation of results from pre-clinical to clinical trials. It can be concluded that the "cell study to animal study to human trial" pipeline has flaws; however, techniques to improve translation between steps have the potential to enhance the success rate of drug development.

Immune organs can be classified into two categories: 1) primary organs including bone marrow and thymus for the generation of immune cells; and 2) secondary organs like tonsils, Peyer's patch, lymph nodes and spleen in which immune cells are programmed toward specific antigens. ${ }^{[59]}$ Recent efforts towards engineering immune tissues in vitro improve the biological relevance of models compared to 2D cell culture. The adoption of human cells into artificial constructs have the potential to form systems with better human relevance than animal models. Modeling immune organs in vitro also facilitates tunable immune system parameters enabling investigation into the fundamental development of the immune system, including immune cell development, recruitment, selection, and activation. ${ }^{[60]}$ In vitro models can also enable the development of immunotherapies like vaccines, antibodies, or antigen-specific T cells. ${ }^{[61]}$

Despite the relatively small size of immune organs in comparison to other organs like the heart or brain, the high structural complexity of immune tissues complicate their in vitro engineering. Immune organs are characterized by high variety and density of cells, dynamic 
ECMs, and constant migration of immune cells. The spatiotemporally dynamic cell-cell and cell-ECM interactions in immune organs further complicate their modeling in vitro. ${ }^{\text {[62] }}$ Despite the in vivo complexity, biomaterial scaffolds are often designed to mimic the ECM of immune tissues through the replication of physical and chemical properties such as stiffness and signaling factors. ${ }^{[63]}$ To replicate the dynamic structure of the immune organs, various types of biomaterials were developed to fit the dynamics of immune organs. ${ }^{[64]}$

Significant effort has been invested in the development of microfluidic organ-on-a-chip models for tracking immune cells. For example, Kim et al. investigated the interactions between $\mathrm{T}$ cells and adhesion molecules in the inflammatory response. ${ }^{[65]}$ Another study, by Jones and colleagues, tracked the migration of neutrophils and monocytes to an inflammation site in order to screen inflammation-regulating drugs. ${ }^{[66]}$ In addition, immune cell migration from one chamber to bacteria in another chamber was monitored in a microfluidic device to investigate immune response to infections. ${ }^{[67]}$ Furthermore, the Swartz group has shown that immobilized chemokine gradients played an important role in the migration of dendritic cells. ${ }^{[68]}$ The interactions between cytotoxic $\mathrm{T}$ cells and antigen presenting cells were also modeled to study T cell activation. ${ }^{[69]}$ While each of these methods provided information on a single component of the multicellular immune system, broader organotypic approaches with better relevance to the complex microenvironment of immune tissues are desired in the future.

\subsection{Bone marrow-on-a-chip}

Bone marrow is a generative immune organ. Modeling the bone marrow in vitro could lead to a better understanding of the lineage, commitment, and self-renewal of hematopoietic stem cells (HSC) in the hematopoiesis process. ${ }^{[70]}$ These models also hold the potential to produce hematopoietic cells and immune cells in vitro, working as a biosynthesis tool for generating various therapeutics. Like other organoids, bone marrow organoids facilitate the development and testing of marrow-targeting drugs. Due to bone marrow's relation to radiation therapy, chip devices are also important tools in simulating and alleviating radiation-induced toxicity.

To mimic the ECM of bone marrow, porous scaffolds were constructed to mimic the endogenous porosity of bone marrow ${ }^{[71]}$ that is essential for efficient cell attachment and nutrient transportation. ${ }^{[72]}$ Kotov and coworkers showed that the inverted colloidal crystal approach, using polystyrene beads as a template, can be applied to the engineering of a 3D matrix with tunable porosity. ${ }^{[73]}$ With silicate and poly-acrylamide hydrogel-based scaffolds, anionic clay platelets and poly(diallyldimethylammonium chloride) (PDDA) were deposited in a layer-by-layer approach; this matrix supported the growth of bone marrow stromal cell line, HS-5, and Human CD34 ${ }^{+}$HSCs. This work suggested that the 3D scaffold has a niche for supporting hematopoiesis and can enhance the interactions between stromal cells and the HSCs. Robust expansion of HSCs (CD34 $)$ and differentiation of B cells can be observed in this scaffold as well, where functional B cells could be detected. Sieber et al. constructed a 3D scaffold using hydroxyapatite-coated zirconium oxide to replicate bone marrow's natural ability to maintain the stemness of stem cells. ${ }^{[74]}$ By lining the scaffold with a layer of mesenchymal stem cells (MSCs), the structure was preconditioned for hematopoietic stem 
and progenitor cell (HSPCs) culture. A microfluidic device was also incorporated to provide nutrients and simulate the dynamic microenvironment of bone marrow. The preconditioning of the scaffold in addition to the simulation of fluid flow in the microfluidic device extended the lifespan of stem cells (28 days) while maintaining their multipotency.

In another study, Torisawa et al. demonstrated a "bone marrow-on-a-chip" system to investigate radiation mediated toxicities (Figure 4). ${ }^{[75]}$ The scaffold was formed by a cylindrical PDMS device with a central compartment filled with bone-forming factor and collagen gel. The scaffold was subcutaneously implanted into a mouse and harvested after 8 weeks. The marrow that had grown in the scaffold was primarily composed of hematopoietic cells with a small percentage of adipocytes. The bone marrow-derived scaffold was then cultured in its original PDMS device with microfluidic channels to construct the "bone marrow-on-a-chip". This engineered bone marrow produced the necessary factors to support the growth of hematopoietic cells in vitro. Moreover, microfluidic sampling allowed for facile monitoring of cell behavior during exposure to $\gamma$-radiation and the countermeasure drug, granulocyte colony-stimulating factor.

\subsection{D modeling of Thymus}

The thymus is a compartmentalized immune system organ composed of the cortex and medulla in which two epithelial cell types reside: cortical thymic epithelial cells and medullary thymic epithelial cells. ${ }^{[76]}$ It is also composed of many types of stromal cells, such as endothelial cells, fibroblasts, and antigen-presenting cells (APCs). There have been some efforts to emulate partial structural or functional characteristics of the thymus. Poznansky et al. used a carbon network coated with tantalum as a scaffold (characterized by ridged surface for cell attachment and high surface to volume ratio) to support the growth of a layer of stromal cells. ${ }^{[77]}$ The biological intra-thymic microenvironment was recreated with a mixture of different cell types in the stroma - primary hematopoietic progenitor cells were also co-cultured in the microenvironment. Within 14 days, the synthetic thymus generated mature $\mathrm{T}$ cells, $70 \%$ of which were $\mathrm{CD} 3+\mathrm{T}$ cells. $\mathrm{CD} 3$ was co-expressed in all CD4+ cells and most CD8+ cells. The expression of T cell receptors was detected on CD3+ $T$ cells. Other aspects of thymus physiology have also been simulated using artificial scaffolds; another study adapted a 3D organotypic system typically used for culturing skin to model the developmental progress of epithelial cells (TECs and mTECs) in the thymus. ${ }^{[78]}$

In addition to synthetic scaffolds, other recent studies have reported the use of the natural ECM of the thymus (composed of laminin, collagen, and fibronectin) to support artificial thymus growth in vitro. ${ }^{[79]}$ To recreate the natural composition of the ECM for in vitro thymus generation, decellularized thymus scaffolds were used. ${ }^{\left[{ }^{[0]}\right.}$ Another study demonstrated that decellularized ECM supports the growth of epithelial cells and that the 3D artificial thymus attracted lymphocyte progenitors to regulate allograft tolerance after implantation in an athymic mouse model. ${ }^{[81]}$

Despite the extensive effort devoted to generating thymus organoids, in vitro thymus modeling is still a challenging task. Thus far, only partial thymic functions have been replicated in 3D organoids. ${ }^{[82]}$ Future thymus models must be developed to emulate the more complicated functions of the thymus, such as $\mathrm{T}$ cell selection and maturation. These 
complex processes will depend on the development of scaffolds and fabrication methods that allow the proliferation of various types of primary cells in a spatial-temporally organized manner.

\subsection{Lymph node-on-a-chip}

The lymph nodes organize interactions between immune cells and lymph fluid to build adaptive immunity. ${ }^{[83]}$ The nodes have an ECM composed of follicular dendritic cells and follicular reticular cells that facilitate the migration of major immune cells, such as dendritic cells, B cells, and T cells. Each node has an outer layer in which dendritic cells sample antigens in the afferent fluid, and an inner region dedicated to the activation of B cells (germinal center) and T cells ( $\mathrm{T}$ cell zone).

The function of the lymph node to adapt immune cells towards specific antigens has drawn interest to its in vitro modeling for the purpose of generating immunotherapies. ${ }^{[84]}$ Humoral $\mathrm{B}$ cells that secrete low-affinity antibodies undergo a germinal center-mediated reaction to generate high-affinity antibodies. ${ }^{[85]}$ Purwada et al. simulated the function of the B cell zone in the lymph node to induce germinal center-like phenotypes in naive B cells (Figure 5). ${ }^{[86]}$ In this study, gelatin hydrogels were crosslinked with silicate nanoparticles to provide the 3D scaffold. Fibroblasts were engineered to simulate follicular $\mathrm{T}$ helper cells in the germinal center by transfecting them with $\mathrm{CD} 40 \mathrm{~L}$ and BAFF (the genes responsible for the germinal center-like phenotype of B cells). The in vitro 3D model of the lymph node enabled control of the kinetics of B cell phenotype transformation and antibody class switching. In contrast to this model, the transformation of B cells in 2D cell culture was transient and short-lived. ${ }^{[87]}$ The researchers further modified this design, replacing gelatin with crosslinked poly(ethylene glycol) (PEG), to enable investigation of the effect of integrin on B cell fate. [88]

For T cell-oriented modeling, macroporous PEG scaffolds filled with collagen have been demonstrated to facilitate rapid migration of $T$ cells. ${ }^{[89]}$ These scaffolds simulate the migration of $\mathrm{T}$ cells towards the chemokine CCL21. Rosa et al. designed a microfluidic device with a dendritic cell layer attached to the channel to investigate the dynamics of $\mathrm{T}$ cell maturation. ${ }^{[90]}$ This design replicated the $\mathrm{T}$ cell zone in the lymph node, where the migratory $\mathrm{T}$ cells are programmed by resident dendritic cells that present specific antigens. $\mathrm{T}$ cells migrated towards the dendritic cells irrespective of the fluid flow and the antigenspecificity increased the interaction between $\mathrm{T}$ cells and the dendritic cell layer. Ross et al. developed a hybrid chip that integrated a primary lymph node slice into a microfluidic chip for spatially-precise stimulation of the lymph node. ${ }^{[91]}$ Local response to stimulation of the lymph node, such as a dextran modified with FITC or glucose conjugated with bovine serum albumin, were tested and the system demonstrated in vivo-like behaviors of the lymph node section. This "lymph node-on-a-chip" strategy provides one approach to study local functions of a lymph node, which can be a platform for the development of immunotherapies. VaxDesign (Orlando, FL) has commercialized an in vitro lymph node model, the Lymphoid Tissue Equivalent (LTE) module, that integrated dendritic cells, $\mathrm{T}$ cells, and B cells for predicting the efficacy of vaccines against infections. The platform termed Modular IMmune In vitro Construct (MIMIC®) can help predicting an individual's 
response to a given vaccine by generating activated $\mathrm{T}$ cells, cytokines, and antibodies with a precision higher than PBMC assays. With experience gained from the exploratory research involving several immune organs in vitro, we expect to see additional studies simulating other immune tissues, such as thyroids or spleens, using microfluidic chip techniques.

\section{Conclusions and future perspectives}

Organotypic cancer and immune models that emulate the 3D physiology of organs are promising tools in preclinical testing of drugs. In this review, we discussed the "cancer-on-achip" and "immune organs-on-a-chip" systems that enable facile investigation of dynamic behaviors of cancer and immune cells (Table 1). Most of these lab-on-chip devices are still prototype demonstrations of early-stage concepts. There are some hurdles that need to be addressed before widespread integration of these platforms into preclinical drug development: 1) The availability of patient-derived tissues. Clinical regulations and patient consent may limit accessibility to primary tissue samples. ${ }^{[92]}$ Therefore, these projects demand interdisciplinary cooperation between engineers, clinicians, patients, and policymakers to ensure primary tissue samples are collected safely, lawfully, and ethically.

2) Lab-on-a-chip systems are based on esoteric microfabrication technologies.

Microfabrication facilities and the related expertise are not readily available to all researchers. Commercially available services that provide custom-designed, applicationspecific micro-devices should be developed to give more researchers access to the 3D disease modeling field.

The "cancer-on-a-chip" and "immune organs-on-a-chip" approaches for disease modeling are still in their infancy, which means there are a lot of opportunities ahead, for example:

1. "Cancer-on-a-chip" and "immune organs-on-a-chip" have advantages over 2D cell culture, but they are still years away from competing with in vivo animal models to predict clinical responses. This calls for designing better platforms to replicate the in vivo microenvironment, improving our understanding of pathophysiology, and developing better tissue culture and characterization techniques. ${ }^{[93]}$ Considering the ability of in vitro $3 \mathrm{D}$ models to adopt human-derived tissues, microfluidic organoid chip devices have the potential to compete with animal models in the search for more relevant non-human models of drug response and disease.

2. One important component in the tumor microenvironment is the co-existence of immune cells. ${ }^{[94]}$ Recent breakthroughs in cancer immunotherapies have caused interest in the development of high-throughput in vitro models for simulating cancer-immune system interactions. ${ }^{[95]}$ However, the investigation of cancer immunotherapies using organ-on-achip systems is still in its early stages. Integrating efforts in cancer-on-a-chip and immune system-on-a-chip could shed light on in vitro cancer immunotherapy investigations, such as penetration of tumor by immune cells, and lead to the next generation of effective cancer remedies.

3. One long-sought goal in tissue engineering is to generate functional human tissues in vitro for tissue replacement and regenerative therapies. With improved "immune organs-on-a- 
chip" technologies, it is possible for personalized immune organs to be generated for implantation; these organs could be essential in the fight against autoimmune diseases, cancer, and infections. For example, it may be possible to implant a functional organ to regenerate the failed immune system in HIV-infected patients, ${ }^{[96]}$ substitute well-developed immune organs for underdeveloped ones, ${ }^{[97]}$ or reinvigorate a patient's immune defense in the fight against cancer. ${ }^{[98]}$

In conclusion, "cancer-on-a-chip" and "immune organs-on-a-chip" are promising platforms to facilitate the development of cancer and immune therapies. To realize this potential, it calls for collective efforts from the patients, physicians, engineers, policy makers, and the industry.

\section{Acknowledgement}

The authors declare no conflict of interests in this work. This work has been supported by the National Institutes of Health (1U01CA214411-01A1, 1R01GM126571-01).

\section{References:}

[1]. Prasad V, Mailankody S, JAMA Intern. Med. 2017, 177, 1569. [PubMed: 28892524]

[2]. Shah SB, Singh A, Acta Biomater. 2017, 53, 29. [PubMed: 28159716]

[3]. Shehab N, Lovegrove MC, Geller AI, Rose KO, Weidle NJ, Budnitz DS, JAMA 2016, 316, 2115. [PubMed: 27893129]

[4]. Ben-David U, Ha G, Tseng Y-Y, Greenwald NF, Oh C, Shih J, McFarland JM, Wong B, Boehm JS, Beroukhim R, Golub TR, Nat. Genet. 2017, 49, 1567. [PubMed: 28991255]

[5] a). Zhang B, Korolj A, Lai BFL, Radisic M, Nat. Rev. Mater. 2018, 3, 257;b)Aref AR, Huang RY, Yu W, Chua KN, Sun W, Tu TY, Bai J, Sim WJ, Zervantonakis IK, Thiery JP, Kamm RD, Integr. Biol. 2013, 5, 381.

[6]. Rios AC, Clevers H, Nat. Methods 2018, 15, 24. [PubMed: 29298292]

[7] a). Yui S, Nakamura T, Sato T, Nemoto Y, Mizutani T, Zheng X, Ichinose S, Nagaishi T, Okamoto R, Tsuchiya K, Clevers H, Watanabe M, Nat. Med. 2012, 18, 618; [PubMed: 22406745] b)Fordham Robert P., Yui S, Hannan Nicholas R. F., Soendergaard C, Madgwick A, Schweiger Pawel J., Nielsen Ole H., Vallier L, Pedersen Roger A., Nakamura T, Watanabe M, Jensen Kim B., Cell Stem Cell 2013, 13, 734. [PubMed: 24139758]

[8]. Jürgen G, Thomas B, Torsten B, Jason AB, Dong-Woo C, Paul DD, Brian D, Gabor F, Qing L, Vladimir AM, Lorenzo M, Makoto N, Wenmiao S, Shoji T, Giovanni V, Tim BFW, Tao X, James JY, Jos M, Biofabrication 2016, 8, 013001. [PubMed: 26744832]

[9] a). Moroni L, Burdick JA, Highley C, Lee SJ, Morimoto Y, Takeuchi S, Yoo JJ, Nat. Rev. Mater. 2018, 3, 21;b)Costantini M, Idaszek J, Szoke K, Jaroszewicz J, Dentini M, Barbetta A, Brinchmann JE, Swieszkowski W, Biofabrication 2016, 8, 035002. [PubMed: 27431574]

[10] a). Wegst UGK, Bai H, Saiz E, Tomsia AP, Ritchie RO, Nat. Mater. 2014, 14, 23; [PubMed: 25344782] b)Wysocki B, Idaszek J, Zdunek J, Rozniatowski K, Pisarek M, Yamamoto A, Swieszkowski W, Int. J. Mol. Sci. 2018, 19, 1619; c)Chlanda A, Kijenska E, Rinoldi C, Tarnowski M, Wierzchon T, Swieszkowski W, Micron 2018, 107, 79; [PubMed: 29453143] d)Su T, Huang K, Daniele MA, Hensley MT, Young AT, Tang J, Allen TA, Vandergriff AC, Erb PD, Ligler FS, Cheng K, ACS Appl. Mater. Inter. 2018, 10, 33088.

[11]. Wong SY, Soto J, Li S, Curr. Opin. Chem. Eng. 2017, 15, 95. [PubMed: 28413770]

[12]. Joyce JA, Fearon DT, Science 2015, 348, 74. [PubMed: 25838376]

[13] a). Carmona-Fontaine C, Deforet M, Akkari L, Thompson CB, Joyce JA, Xavier JB, Proc. Natl. Acad. Sci. U. S. A. 2017;b)Vandergriff A, Huang K, Shen D, Hu S, Hensley MT, Caranasos TG, Qian L, Cheng K, Theranostics 2018, 8, 1869. [PubMed: 29556361] 
[14]. Jager M, Blokzijl F, Sasselli V, Boymans S, Janssen R, Besselink N, Clevers H, van Boxtel R, Cuppen E, Nat. Protocols 2017, 13, 59. [PubMed: 29215633]

[15]. Packard RRS, Baek KI, Beebe T, Jen N, Ding Y, Shi F, Fei P, Kang BJ, Chen PH, Gau J, Chen M, Tang JY, Shih YH, Ding Y, Li D, Xu X, Hsiai TK, Sci. Rep. 2017, 7, 8603. [PubMed: 28819303]

[16]. Huh D, Matthews BD, Mammoto A, Montoya-Zavala M, Hsin HY, Ingber DE, Science 2010, 328, 1662. [PubMed: 20576885]

[17]. Kimura H, Sakai Y, Fujii T, Drug Metab. Pharmacok. 2018, 33, 43.

[18]. Rackus DG, Shamsi MH, Wheeler AR, Chem. Soc. Rev. 2015, 44, 5320. [PubMed: 25962356]

[19]. Dekkers JF, Berkers G, Kruisselbrink E, Vonk A, de Jonge HR, Janssens HM, Bronsveld I, van de Graaf EA, Nieuwenhuis EES, Houwen RHJ, Vleggaar FP, Escher JC, de Rijke YB, Majoor CJ, Heijerman HGM, de Winter-de Groot KM, Clevers H, van der Ent CK, Beekman JM, Sci. Transl. Med. 2016, 8, 344ra84.

[20]. Qiu Y, Ahn B, Sakurai Y, Hansen CE, Tran R, Mimche PN, Mannino RG, Ciciliano JC, Lamb TJ, Joiner CH, Ofori-Acquah SF, Lam WA, Nat. Biomed. Eng. 2018, 2, 453. [PubMed: 30533277]

[21]. Paşca SP, Nature 2018, 553, 437. [PubMed: 29364288]

[22]. Musah S, Mammoto A, Ferrante TC, Jeanty SSF, Hirano-Kobayashi M, Mammoto T, Roberts K, Chung S, Novak R, Ingram M, Fatanat-Didar T, Koshy S, Weaver JC, Church GM, Ingber DE, Nat. Biomed. Eng. 2017, 1, 0069. [PubMed: 29038743]

[23]. Sherman MH, Yu RT, Tseng TW, Sousa CM, Liu S, Truitt ML, He N, Ding N, Liddle C, Atkins AR, Leblanc M, Collisson EA, Asara JM, Kimmelman AC, Downes M, Evans RM, Proc. Natl. Acad. Sci. U. S. A. 2017, 114, 1129. [PubMed: 28096419]

[24]. Albini A, Sporn MB, Nat. Rev. Cancer 2007, 7, 139. [PubMed: 17218951]

[25]. Abbasi J, JAMA 2018, 319, 1427.

[26]. Sachs N, de Ligt J, Kopper O, Gogola E, Bounova G, Weeber F, Balgobind AV, Wind K, Gracanin A, Begthel H, Korving J, van Boxtel R, Duarte AA, Lelieveld D, van Hoeck A, Ernst RF, Blokzijl F, Nijman IJ, Hoogstraat M, van de Ven M, Egan DA, Zinzalla V, Moll J, Boj SF, Voest EE, Wessels L, van Diest PJ, Rottenberg S, Vries RGJ, Cuppen E, Clevers H, Cell 2018, 172, 373. [PubMed: 29224780]

[27]. van de Wetering M, Francies Hayley E., Francis Joshua M., Bounova G, Iorio F, Pronk A, van Houdt W, van Gorp J, Taylor-Weiner A, Kester L, McLaren-Douglas A, Blokker J, Jaksani S, Bartfeld S, Volckman R, van Sluis P, Li Vivian S. W., Seepo S, Sekhar Pedamallu C, Cibulskis K, Carter Scott L., McKenna A, Lawrence Michael S., Lichtenstein L, Stewart C, Koster J, Versteeg R, van Oudenaarden A, Saez-Rodriguez J, Vries Robert G. J., Getz G, Wessels L, Stratton Michael R., McDermott U, Meyerson M, Garnett Mathew J., Clevers H, Cell 2015, 161, 933. [PubMed: 25957691]

[28] a). Stone L, Nat. Rev. Urol. 2018, 15, 397; [PubMed: 29725126] b)Lee SH, Hu W, Matulay JT, Silva MV, Owczarek TB, Kim K, Chua CW, Barlow LJ, Kandoth C, Williams AB, Bergren SK, Pietzak EJ, Anderson CB, Benson MC, Coleman JA, Taylor BS, Abate-Shen C, McKiernan JM, Al-Ahmadie H, Solit DB, Shen MM, Cell 2018, 173, 515. [PubMed: 29625057]

[29]. Vlachogiannis G, Hedayat S, Vatsiou A, Jamin Y, Fernandez-Mateos J, Khan K, Lampis A, Eason K, Huntingford I, Burke R, Rata M, Koh DM, Tunariu N, Collins D, Hulkki-Wilson S, Ragulan C, Spiteri I, Moorcraft SY, Chau I, Rao S, Watkins D, Fotiadis N, Bali M, DarvishDamavandi M, Lote H, Eltahir Z, Smyth EC, Begum R, Clarke PA, Hahne JC, Dowsett M, de Bono J, Workman P, Sadanandam A, Fassan M, Sansom OJ, Eccles S, Starling N, Braconi C, Sottoriva A, Robinson SP, Cunningham D, Valeri N, Science 2018, 359, 920. [PubMed: 29472484]

[30] a). Boj Sylvia F., Hwang C-I, Baker Lindsey A., Chio Iok In C., Engle Dannielle D., Corbo V, Jager M, Ponz-Sarvise M, Tiriac H, Spector Mona S., Gracanin A, Oni T, Yu Kenneth H., van Boxtel R, Huch M, Rivera Keith D., Wilson John P., Feigin Michael E., Öhlund D, HandlySantana A, Ardito-Abraham Christine M., Ludwig M, Elyada E, Alagesan B, Biffi G, Yordanov Georgi N., Delcuze B, Creighton B, Wright K, Park Y, Morsink Folkert H. M., Molenaar IQ, Borel Rinkes Inne H., Cuppen E, Hao Y, Jin Y, Nijman Isaac J., Iacobuzio-Donahue C, Leach Steven D., Pappin Darryl J., Hammell M, Klimstra David S., Basturk O, Hruban Ralph H., Offerhaus George J., Vries Robert G. J., Clevers H, Tuveson David A., Cell 2015, 160, 324; 
[PubMed: 25557080] b)Romero Calvo I, Weber CR, Ray M, Brown MA, Kirby KJ, Nandi RK, Long TM, Sparrow SM, Ugolkov AV, Qiang W, Zhang Y, Brunetti TM, Kindler HL, Segal JP, Rzhetsky A, Mazar AP, Buschmann MM, Weichselbaum RR, Rogin KK, White KP, Mol. Cancer Res. 2018, DOI: 10.1158/1541-7786.MCR-18-0531.

[31]. Broutier L, Mastrogiovanni G, Verstegen MMA, Francies HE, Gavarró LM, Bradshaw CR, Allen GE, Arnes-Benito R, Sidorova O, Gaspersz MP, Georgakopoulos N, Koo B-K, Dietmann S, Davies SE, Praseedom RK, Lieshout R, Ijzermans JNM, Wigmore SJ, Saeb-Parsy K, Garnett MJ, van der Laan LJW, Huch M, Nat. Med. 2017, 23, 1424. [PubMed: 29131160]

[32]. Weber C, Nat. Cell Biol. 2018, 20, 634.

[33]. Buzzelli JN, Ouaret D, Brown G, Allen PD, Muschel RJ, Stem Cell Res. 2018, 27, 109. [PubMed: 29414601]

[34] a). Peela N, Sam FS, Christenson W, Truong D, Watson AW, Mouneimne G, Ros R, Nikkhah M, Biomaterials 2016, 81, 72; [PubMed: 26724455] b)Yu M, Bardia A, Aceto N, Bersani F, Madden MW, Donaldson MC, Desai R, Zhu H, Comaills V, Zheng Z, Wittner BS, Stojanov P, Brachtel E, Sgroi D, Kapur R, Shioda T, Ting DT, Ramaswamy S, Getz G, Iafrate AJ, Benes C, Toner M, Maheswaran S, Haber DA, Science 2014, 345, 216. [PubMed: 25013076]

[35] a). Qian X, Jacob F, Song MM, Nguyen HN, Song H, Ming G.-1., Nat. Protocols 2018, 13, 565; [PubMed: 29470464] b)Dai X, Ma C, Lan Q, Xu T, Biofabrication 2016, 8, 045005. [PubMed: 27725343]

[36]. Zhao Y, Yao R, Ouyang L, Ding H, Zhang T, Zhang K, Cheng S, Sun W, Biofabrication 2014, 6, 035001. [PubMed: 24722236]

[37]. Puca L, Bareja R, Prandi D, Shaw R, Benelli M, Karthaus WR, Hess J, Sigouros M, Donoghue A, Kossai M, Gao D, Cyrta J, Sailer V, Vosoughi A, Pauli C, Churakova Y, Cheung C, Deonarine LD, McNary TJ, Rosati R, Tagawa ST, Nanus DM, Mosquera JM, Sawyers CL, Chen Y, Inghirami G, Rao RA, Grandori C, Elemento O, Sboner A, Demichelis F, Rubin MA, Beltran H, Nat. Commun. 2018, 9, 2404. [PubMed: 29921838]

[38]. Weeber F, van de Wetering M, Hoogstraat M, Dijkstra KK, Krijgsman O, Kuilman T, Gadellaavan Hooijdonk CGM, van der Velden DL, Peeper DS, Cuppen EPJG, Vries RG, Clevers H, Voest EE, Proc. Natl. Acad. Sci. U. S. A. 2015, 112, 13308. [PubMed: 26460009]

[39]. Majumder B, Baraneedharan U, Thiyagarajan S, Radhakrishnan P, Narasimhan H, Dhandapani M, Brijwani N, Pinto DD, Prasath A, Shanthappa BU, Thayakumar A, Surendran R, Babu GK, Shenoy AM, Kuriakose MA, Bergthold G, Horowitz P, Loda M, Beroukhim R, Agarwal S, Sengupta S, Sundaram M, Majumder PK, Nat. Commun. 2015, 6, 6169. [PubMed: 25721094]

[40] a). Salahudeen AA, Kuo CJ, Nat. Med. 2015, 21, 215; [PubMed: 25742455] b)Drost J, van Jaarsveld RH, Ponsioen B, Zimberlin C, van Boxtel R, Buijs A, Sachs N, Overmeer RM, Offerhaus GJ, Begthel H, Korving J, van de Wetering M, Schwank G, Logtenberg M, Cuppen E, Snippert HJ, Medema JP, Kops GJPL, Clevers H, Nature 2015, 521, 43. [PubMed: 25924068]

[41]. Matano M, Date S, Shimokawa M, Takano A, Fujii M, Ohta Y, Watanabe T, Kanai T, Sato T, Nat. Med. 2015, 21, 256. [PubMed: 25706875]

[42]. Zafra MP, Schatoff EM, Katti A, Foronda M, Breinig M, Schweitzer AY, Simon A, Han T, Goswami S, Montgomery E, Thibado J, Kastenhuber ER, Sánchez-Rivera FJ, Shi J, Vakoc CR, Lowe SW, Tschaharganeh DF, Dow LE, Nat. Biotechnol. 2018.

[43]. Zhang B, Montgomery M, Chamberlain MD, Ogawa S, Korolj A, Pahnke A, Wells Laura A., Massé S, Kim J, Reis L, Momen A, Nunes Sara S., Wheeler AR, Nanthakumar K, Keller G, Sefton Michael V., Radisic M, Nat. Mater. 2016, 15, 669. [PubMed: 26950595]

[44]. Zervantonakis IK, Hughes-Alford SK, Charest JL, Condeelis JS, Gertler FB, Kamm RD, Proc. Natl. Acad. Sci. U. S. A. 2012, 109, 13515. [PubMed: 22869695]

[45]. Jeon JS, Bersini S, Gilardi M, Dubini G, Charest JL, Moretti M, Kamm RD, Proc. Natl. Acad. Sci. U. S. A. 2015, 112, 214. [PubMed: 25524628]

[46]. Vickerman V, Kamm RD, Integr. Biol. 2012, 4, 863.

[47]. Sung KE, Yang N, Pehlke C, Keely PJ, Eliceiri KW, Friedl A, Beebe DJ, Integr. Biol. 2011, 3, 439.

[48]. Polacheck WJ, Charest JL, Kamm RD, Proc. Natl. Acad. Sci. U. S. A. 2011, 108, 11115. [PubMed: 21690404] 
[49]. Song JW, Cavnar SP, Walker AC, Luker KE, Gupta M, Tung Y-C, Luker GD, Takayama S, PloS One 2009, 4, e5756. [PubMed: 19484126]

[50]. Zhang YS, Aleman J, Shin SR, Kilic T, Kim D, Mousavi Shaegh SA, Massa S, Riahi R, Chae S, Hu N, Avci H, Zhang W, Silvestri A, Sanati Nezhad A, Manbohi A, De Ferrari F, Polini A, Calzone G, Shaikh N, Alerasool P, Budina E, Kang J, Bhise N, Ribas J, Pourmand A, Skardal A, Shupe T, Bishop CE, Dokmeci MR, Atala A, Khademhosseini A, Proc. Natl. Acad. Sci. U. S. A. 2017, 114, E2293. [PubMed: 28265064]

[51] a). Zhang YS, Zhang Y-N, Zhang W, Drug Discov. Today 2017, 22, 1392; [PubMed: 28390929] b)Portillo-Lara R, Annabi N, Lab Chip 2016, 16, 4063; [PubMed: 27605305] Wang Y, Cuzzucoli F, Escobar A, Lu S, Liang L, Wang S, Nanotechnology 2018, 29, 332001; [PubMed: 29794338] Tsai H-F, Trubelja A, Shen AQ, Bao G, Soc JR. Interface 2017, 14, 20170137; [PubMed: 28637915] c)Ma Y-HV, Middleton K, You L, Sun Y, Microsyst. Nanoeng. 2018, 4, 17104;d)Hachey SJ, Hughes CCW, Lab Chip 2018, 18, 2893. [PubMed: 30156248]

[52]. Sahin U, Tureci O, Science 2018, 359, 1355. [PubMed: 29567706]

[53] a). Prasad V, Nat. Rev. Clin. Oncol. 2017, 15, 11; [PubMed: 28975930] b)Flemming A, Nat. Rev. Immunol. 2017, 17, 215; [PubMed: 28345633] c)Morsut L, Roybal KT, Xiong X, Gordley RM, Coyle SM, Thomson M, Lim WA, Cell 2016, 164, 780; [PubMed: 26830878] d)Roybal KT, Williams JZ, Morsut L, Rupp LJ, Kolinko I, Choe JH, Walker WJ, McNally KA, Lim WA, Cell 2016, 167, 419. [PubMed: 27693353]

[54]. Williams RO, Tseng W-Y, Nat. Rev. Rheumatol. 2018, 14, 188. [PubMed: 29559717]

[55]. Bird BH, Spengler JR, Chakrabarti AK, Khristova ML, Sealy TK, Coleman-McCray JD, Martin BE, Dodd KA, Goldsmith CS, Sanders J, Zaki SR, Nichol ST, Spiropoulou CF, J. Infect. Dis. 2016, 213, 703. [PubMed: 26582961]

[56]. Gjoneska E, Pfenning AR, Mathys H, Quon G, Kundaje A, Tsai L-H, Kellis M, Nature 2015, 518, 365. [PubMed: 25693568]

[57]. DeFrancesco L, Nat. Biotechnol. 2017, 35, 6.

[58]. Cadavid D, Balcer L, Galetta S, Aktas O, Ziemssen T, Vanopdenbosch L, Frederiksen J, Skeen M, Jaffe GJ, Butzkueven H, Ziemssen F, Massacesi L, Chai Y, Xu L, Freeman S, Lancet Neurol. 2017, 16, 189. [PubMed: 28229892]

[59]. Brodin P, Davis MM, Nat. Rev. Immunol. 2016, 17, 21. [PubMed: 27916977]

[60]. Shah SB, Singh A, Curr. Opin. Hematol. 2017, 24, 377. [PubMed: 28426555]

[61]. Salazar F, Awuah D, Negm OH, Shakib F, Ghaemmaghami AM, Sci. Rep. 2017, 7, 43337. [PubMed: 28256612]

[62]. Nowarski R, Jackson R, Flavell RA, Cell 2017, 168, 362. [PubMed: 28129537]

[63]. Htwe SS, Cha BH, Yue K, Khademhosseini A, Knox AJ, Ghaemmaghami AM, Am. J. Respir. Cell Mol. Biol. 2017, 56, 772. [PubMed: 28225294]

[64]. Chung L, Maestas DR, Housseau F, Elisseeff JH, Adv. Drug Deliver. Rev. 2017, 114, 184.

[65]. Kim SK, Moon WK, Park JY, Jung H, Analyst 2012, 137, 4062. [PubMed: 22822477]

[66]. Jones CN, Dalli J, Dimisko L, Wong E, Serhan CN, Irimia D, Proc. Natl. Acad. Sci. U. S. A. 2012, 109, 20560. [PubMed: 23185003]

[67]. Gopalakrishnan N, Hannam R, Casoni GP, Barriet D, Ribe JM, Haug M, Halaas O, Lab Chip 2015, 15, 1481. [PubMed: 25608968]

[68]. Haessler U, Pisano M, Wu M, Swartz MA, Proc. Natl. Acad. Sci. U. S. A. 2011, 108, 5614. [PubMed: 21422278]

[69]. Dura B, Dougan SK, Barisa M, Hoehl MM, Lo CT, Ploegh HL, Voldman J, Nat. Commun. 2015, 6, 5940. [PubMed: 25585172]

[70]. Zhou BO, Yu H, Yue R, Zhao Z, Rios JJ, Naveiras O, Morrison SJ, Nat. Cell Biol. 2017, 19, 891. [PubMed: 28714970]

[71]. Lee J, Kotov NA, Small 2009, 5, 1008. [PubMed: 19334013]

[72]. Cha BH, Shin SR, Leijten J, Li YC, Singh S, Liu JC, Annabi N, Abdi R, Dokmeci MR, Vrana NE, Ghaemmaghami AM, Khademhosseini A, Adv. Healthc. Mater. 2017. 
[73]. Nichols JE, Cortiella J, Lee J, Niles JA, Cuddihy M, Wang S, Bielitzki J, Cantu A, Mlcak R, Valdivia E, Yancy R, McClure ML, Kotov NA, Biomaterials 2009, 30, 1071. [PubMed: 19042018]

[74]. Sieber S, Wirth L, Cavak N, Koenigsmark M, Marx U, Lauster R, Rosowski M, J. Tissue Eng. Regen. M 2018, 12, 479. [PubMed: 28658717]

[75]. Torisawa Y.-s., Spina CS, Mammoto T, Mammoto A, Weaver JC, Tat T, Collins JJ, Ingber DE, Nat. Methods 2014, 11, 663. [PubMed: 24793454]

[76]. Takahama Y, Ohigashi I, Baik S, Anderson G, Nat. Rev. Immunol. 2017, 17, 295. [PubMed: 28317923]

[77]. Poznansky MC, Evans RH, Foxall RB, Olszak IT, Piascik AH, Hartman KE, Brander C, Meyer TH, Pykett MJ, Chabner KT, Kalams SA, Rosenzweig M, Scadden DT, Nat. Biotechnol. 2000, 18, 729. [PubMed: 10888839]

[78]. Pinto S, Schmidt K, Egle S, Stark HJ, Boukamp P, Kyewski B, J. Immunol. 2013, 190, 1085. [PubMed: 23269248]

[79]. Tajima A, Pradhan I, Trucco M, Fan Y, Curr. Stem Cell Rep. 2016, 2, 128. [PubMed: 27529056]

[80]. Hun M, Barsanti M, Wong K, Ramshaw J, Werkmeister J, Chidgey AP, Biomaterials 2017, 118, 1. [PubMed: 27940379]

[81]. Fan Y, Tajima A, Goh SK, Geng X, Gualtierotti G, Grupillo M, Coppola A, Bertera S, Rudert WA, Banerjee I, Bottino R, Trucco M, Mol. Ther. 2015, 23, 1262. [PubMed: 25903472]

[82]. Vianello F, Poznansky MC. (2007) Immunological Tolerance: Methods and Protocols, Totowa, NJ: Humana Press.

[83]. Irvine DJ, Stachowiak AN, Hori Y, Semin. Immunol. 2008, 20, 137. [PubMed: 18035552]

[84]. Wang X, Rodda LB, Bannard O, Cyster JG, J. Immunol. 2014, 192, 4601. [PubMed: 24740506]

[85]. Quizon N, Kwak K, Shah S, Singh A, Pierce S, J. Immunol. 2018, 200, 120.14.

[86]. Purwada A, Singh A, Nat. Protocols 2016, 12, 168. [PubMed: 28005068]

[87]. Purwada A, Jaiswal MK, Ahn H, Nojima T, Kitamura D, Gaharwar AK, Cerchietti L, Singh A, Biomaterials 2015, 63, 24. [PubMed: 26072995]

[88] a). Purwada A, Shah SB, Beguelin W, Melnick AM, Singh A, ACS Biomater. Sci. Eng. 2017, 3, 214;b)Purwada A, Shah SB, Béguelin W, August A, Melnick AM, Singh A, Biomaterials 2018.

[89]. Stachowiak AN, Irvine DJ, J. Biomed. Mater. Res. B 2008, 85, 815.

[90]. Moura Rosa P, Gopalakrishnan N, Ibrahim H, Haug M, Halaas O, Lab Chip 2016, 16, 3728. [PubMed: 27560793]

[91]. Ross AE, Belanger MC, Woodroof JF, Pompano RR, Analyst 2017, 142, 649. [PubMed: 27900374]

[92]. Bredenoord AL, Clevers H, Knoblich JA, Science 2017, 355.

[93]. Carragher N, Piccinini F, Tesei A, O. J. T., Jr, Bickle M, Horvath P, Nat. Rev. Drug Discov. 2018.

[94]. Gajewski TF, Schreiber H, Fu Y-X, Nat. Immunol. 2013, 14, 1014. [PubMed: 24048123]

[95]. Boussommier-Calleja A, Li R, Chen MB, Wong SC, Kamm RD, Trends cancer 2016, 2, 6. [PubMed: 26858990]

[96]. Pernet O, Yadav SS, An DS, Adv. Drug Deliver. Rev. 2016, 103, 187.

[97]. Hudson LL, Louise Markert M, Devlin BH, Haynes BF, Sempowski GD, Semin. Immunol. 2007, 19, 297. [PubMed: 18035553]

[98]. Kalos M, June Carl H., Immunity 2013, 39, 49. [PubMed: 23890063] 


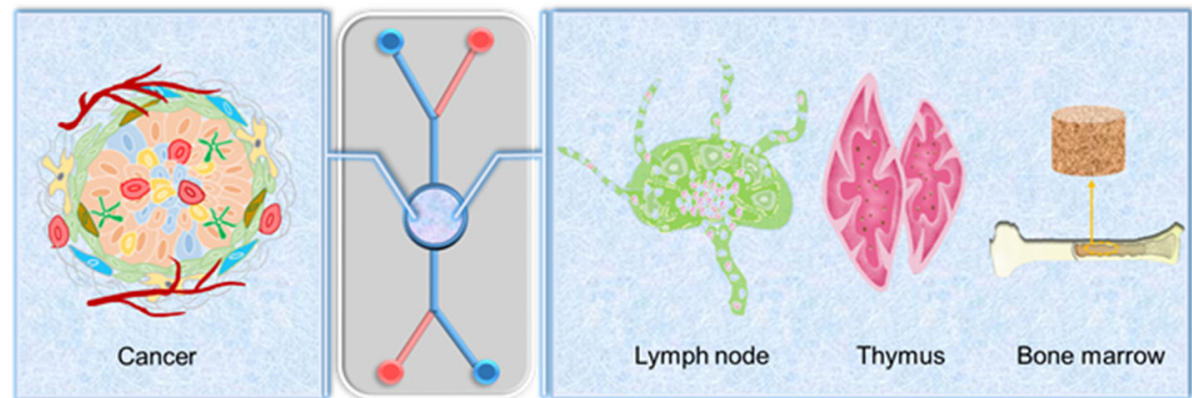

Figure 1.

Modeling cancer and immune organs on microfluidic chips for preclinical drug screening and studying physiological processes. 


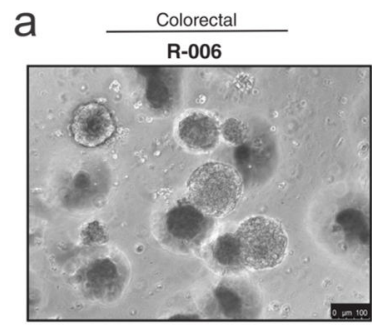

b

Figure 2.
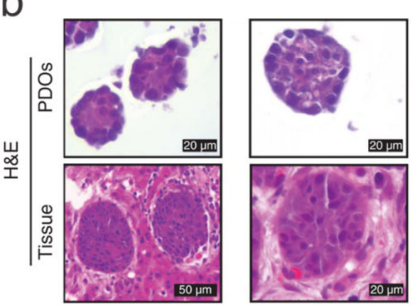

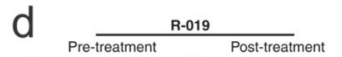
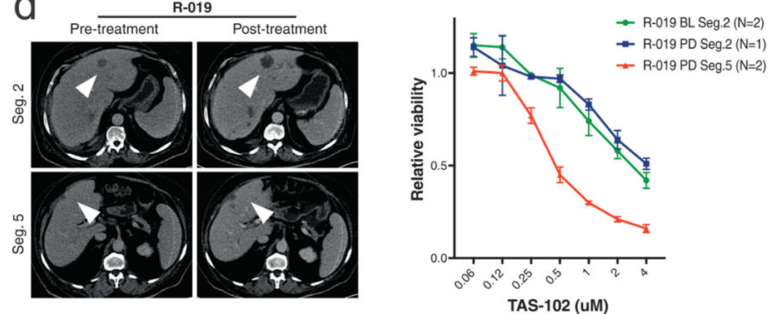

C
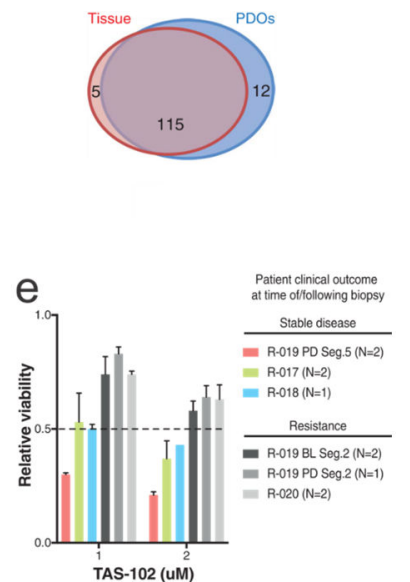

Construction of a 3D model of metastatic human gastrointestinal cancers for predicting clinical drug response. a) Optical imaging of patient-derived organoids (PDOs) from patient R-006. b) Hematoxylin and eosin staining showed the reproduction of in vivo cancer histology in the organoids. c) Sequencing of patient tissue and the PDOs showed $96 \%$ overlap in the mutated genes. d) The organoid model replicated intra-patient cancer variance from patient R-019 in response to TAS-102. e) Inter-patient response variation to TAS-102 was also demonstrated by the organoid models. Reproduced with permission. ${ }^{[29]}$ Copyright 2018, The American Association for the Advancement of Science. 

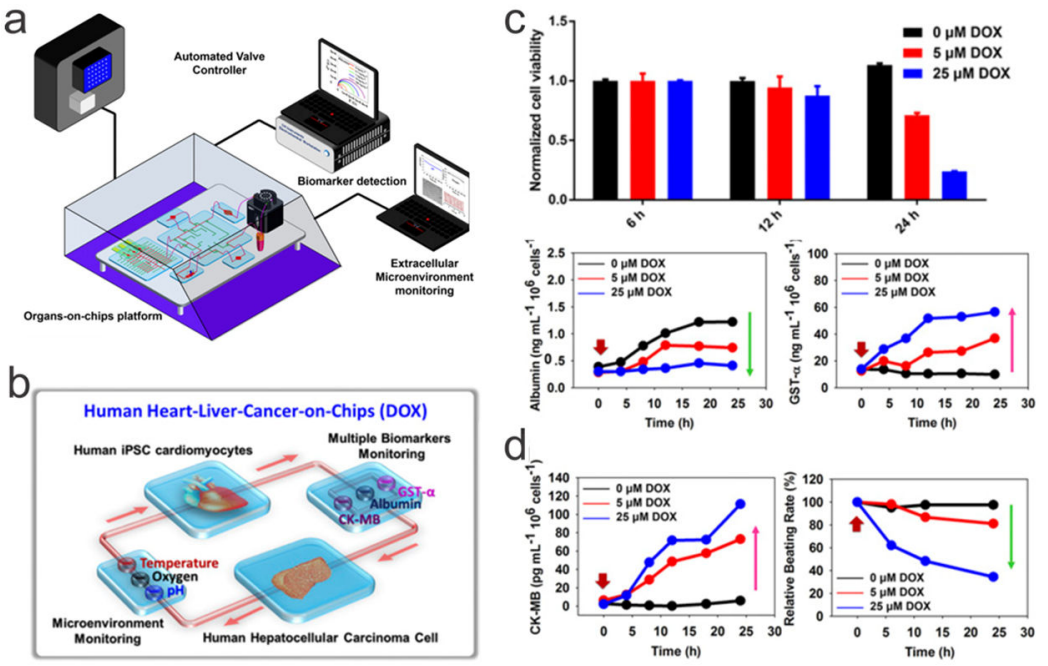

Figure 3.

Multi-sensor-on-a-chip for monitoring anticancer efficacy and cardiac toxicity of DOX. a) An organ-on-a-chip system containing multiple organs and sensors was automatically controlled and monitored. b) Design of the heart-liver-cancer-on-a-chip system. c) Monitoring anticancer efficacy of the administered DOX through viability analysis and biomarker monitoring. d) Cardiac toxicity was observed with increasing concentration of DOX in the microfluidic system. Reproduced with permission. ${ }^{[50]}$ Copyright 2017, National Academy of Sciences. 

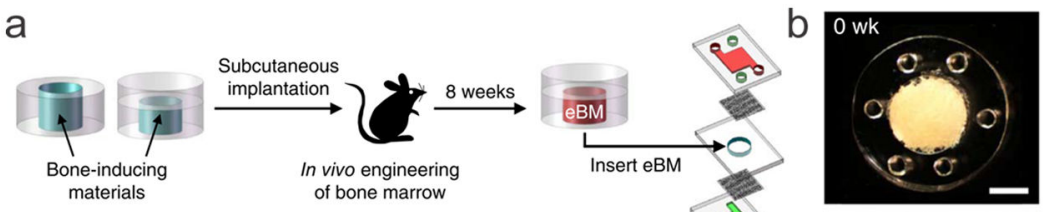

C
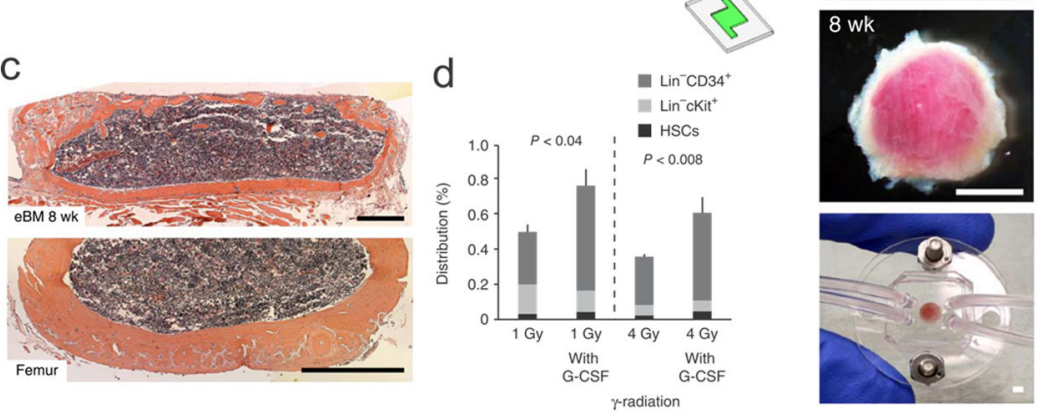

Figure 4.

Bone marrow-on-a-chip. a) A bone-inducing PDMS device was implanted subcutaneously to generate bone marrow in vivo. b) The bone marrow explant was integrated into a microfluidic chip. c) The engineered bone marrow histological patterns resembled those of native mouse bone marrow. Engineered bone marrow (upper) and native mouse bone marrow (lower). d) The bone marrow-on-a-chip model demonstrated the protective effect of G-CSF against $\gamma$-radiation. Reproduced with permission. ${ }^{[75]}$ Copyright 2014 , Springer Nature. 


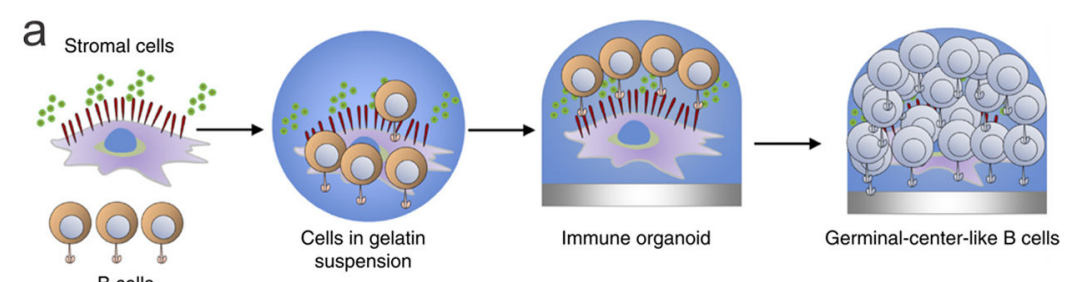

b Organoids on Sigmacen
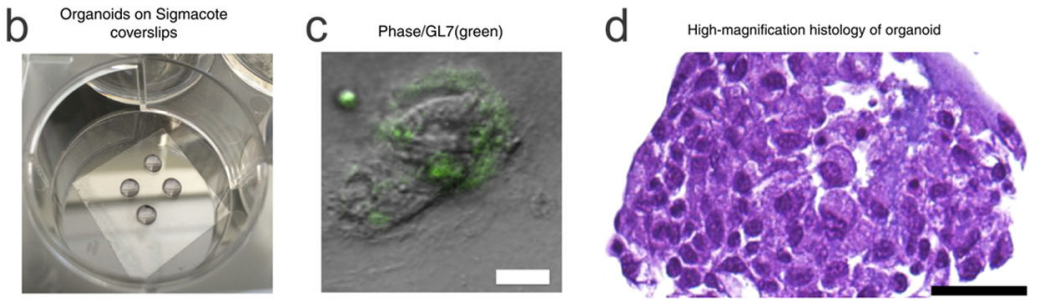

Figure 5.

A lymph node germinal-center-on-a-chip model. a) Co-culture of naive B cells in the 3D scaffold with stromal cells presenting CD40L and secreting BAFF transformed B cells to a germinal center-like phenotype. b) Optical imaging of the whole organoid. c) Bright field and fluorescent imaging of the organoid, green fluorescence-stained germinal center phenotype marker. d) H\&E-staining of the organoid. Reproduced with permission. ${ }^{[86]}$ Copyright 2016, Springer Nature. 
Table 1.

Summary of cancer-on-a-chip and immune organs-on-a-chip systems cited in this review.

\begin{tabular}{|c|c|c|c|}
\hline & Cell source & Scaffold material & Reference \\
\hline \multirow[t]{12}{*}{ Cancer organoids } & Primary breast cancer from patient & $\begin{array}{l}\text { Cultrex Reduced Growth Factor } \\
\text { Basement Membrane Matrix, Type } 2\end{array}$ & [26] \\
\hline & Primary colorectal cancer from patient & $\begin{array}{l}\text { Cultrex Reduced Growth Factor } \\
\text { Basement Membrane Matrix, Type } 2\end{array}$ & [27] \\
\hline & Primary bladder cancer from patient & Matrigel & [28b] \\
\hline & Metastatic gastrointestinal cancer from patient & Matrigel & [29] \\
\hline & Ductal pancreatic cancer from patient & Matrigel & [30a] \\
\hline & Primary liver cancer from patient & $\begin{array}{l}\text { Cultrex Reduced Growth Factor } \\
\text { Basement Membrane Matrix, Type } 2\end{array}$ & [31] \\
\hline & Colorectal cancer (CRC) liver metastasis from patient & Matrigel & [33] \\
\hline & MDA-MB-231, MCF7, MCF10A & Gelatin methacrylate & [34a] \\
\hline & HeLa & Gelatin/alginate/fibrinogen & [36] \\
\hline & Metastatic prostate cancer from patient & Matrigel & [37-38] \\
\hline & Tumor biopsies from patient & $\begin{array}{l}\text { Tumor grade-matched matrix } \\
\text { supplemented with autologous serum }\end{array}$ & [39] \\
\hline & Gene edited intestinal tissue from human & Matrigel & [41] \\
\hline \multirow[t]{7}{*}{ Cancer-on-a-chip } & HT1080, MDA231, RAW264.7 & Collagen type I & [44] \\
\hline & $\begin{array}{l}\text { MDA-MB-231, C2C12, RAW264.7, MCF-10A, GFP- } \\
\text { transfected HUVEC, Primary hBM-MSCs from patient }\end{array}$ & Fibrinogen & [45] \\
\hline & HMVEC, HUVEC, EGM-2MV, EGM-2 & Peptide, matrigel, collagen & [46] \\
\hline & HMF, MCF-DCIS & Collagen, matrigel & [47] \\
\hline & MDA-MB-231 & Collagen type I & [48] \\
\hline & HDMECs, 293T, MDA-MB-231 & - & [49] \\
\hline & $\begin{array}{l}\text { Human primary hepatocytes, HepG2, Human iPSC- } \\
\text { CMs }\end{array}$ & GelMA, fibronogen & [50] \\
\hline \multirow[t]{4}{*}{ Bone marrow-on-a-chip } & CD34+ HSCs from human & Polyacrylamide & [71] \\
\hline & HS-5, hFOB 1.19, CD34+ HSCs from human & Silicate, Polyacrylamide & [73] \\
\hline & HSPCs and MSCs from human & hydroxyapatite coated zirconium oxide & [74] \\
\hline & hematopoietic cells and adipocytes from mouse & Collagen, demineralized bone powder & [75] \\
\hline \multirow[t]{4}{*}{ 3D modeling of Thymus } & Thymic stroma from mouse, HSCs from human & Tantalum-coated carbon matrix & [77] \\
\hline & TECs from mouse, Human dermal fibroblasts & Jettex 3D, fibrinogen & [78] \\
\hline & TECs from E14.5 embryos & Decellularized thymic ECM & [80] \\
\hline & TECs and thymic fibroblasts from mouse & Decellularized thymic ECM & [81] \\
\hline \multirow[t]{6}{*}{ Lymph node-on-a-chip } & $\begin{array}{l}\text { Splenocyte from mouse, BALB/c3T3 fibroblasts } \\
\text { transfected with CD } 40 \mathrm{~L}\end{array}$ & Gelatin, silicate & [86] \\
\hline & Splenocyte from mouse & Gelatin, silicate & [87] \\
\hline & Splenocyte from mouse & PEG, peptide & [88] \\
\hline & $\mathrm{T}$ cell and dendritic cells from mouse & PEG, collagen & [89] \\
\hline & $\mathrm{T}$ cell and dendritic cells from mouse & - & [90] \\
\hline & Lymph node slice from mouse & - & [91] \\
\hline
\end{tabular}

